\title{
Nude vibrating wire piezometer installations - no filter response zone and no engineered grout
}

\author{
AJ Mazur Fugro Geotechnical Services Ltd., Hong Kong \\ LM Schouten Fugro Geotechnical Services Ltd., Hong Kong \\ WY Lam Fugro Geotechnical Services Ltd., Hong Kong \\ PH Setiawan Fugro Geotechnical Services Ltd., Hong Kong
}

\begin{abstract}
This paper presents and compares the field performance of nude vibrating wire piezometer (VWP) installations with conventionally installed VWPs (with bentonite seal and filter response zone). The term 'nude' is used here to describe VWP instruments installed inside drill holes, without any filter response zone, bentonite seals or engineered grout materials. The success of this technique is dependent on the natural soil materials collapsing and enveloping the VWP sensor, forming a satisfactorily impermeable seal.

Once the nude VWP instrument is lowered to the desired depth in a drill hole, the drill hole support casing is quickly removed and the surrounding saturated, soft, fine grained soils are allowed to collapse around and remould above the instrument to provide a relatively impermeable seal. Any remaining open area at the collar of the drill hole is backfilled with drill cuttings.

In 2003 at the Sixth International Symposium on Field Measurements in Geomechanics, VWPs in fully-grouted boreholes were proposed as an acceptable and even superior alternative to the conventional filter sand/bentonite seal response zones commonly used with VWP instruments. Several authors have contributed further research over the ensuing twelve years, and the fully-grouted borehole technique has been adopted by a growing number of practitioners.

We now put forward that under certain geotechnical conditions, the natural ground profile in soft soils can form an adequate low-permeability seal around the piezometer, and the engineered grout used with the fully-grouted borehole method may also be eliminated. In this case study, nude VWP performance was found to be characteristic of readings observed from conventionally (filter zone and bentonite seal) installed VWP instruments. Our findings are the result of full-scale field trials on a major Hong Kong reclamation project covering 150 hectares that were subject to staged loading using a sand surcharge. These piezometers were placed within low permeability, soft marine sediments, with data retrieved automatically during several stages of surcharge loading and unloading.
\end{abstract}

The following arrangements were tested:

- Nude VWP instruments installed without filter response zone, bentonite seals or engineered grout.

- VWP instruments installed with conventional sand filter response zone and upper and lower bentonite seals.

Absolute readings, sensitivity, response times and dissipation signatures were compared in all instruments, in response to a rapidly applied and staged sand surcharge of 10 metres maximum height.

\section{Introduction}

The Hong Kong Boundary Crossing Facilities is a 150 hectare near-shore island reclamation constructed using hydraulic sand fill placed rapidly over soft, young marine deposits. More than 400 VWP instruments have been placed in these marine muds using 'conventional' sand filter response zones and upper and lower bentonite seals. 
In two study areas (Figure 1), additional nude VWP instruments were also installed adjacent to VWP instruments installed using conventional techniques. The term 'nude' is used here to describe VWP instruments installed inside drill holes, without any filter response zone, bentonite seals and without any engineered grout materials. The drill casing was quickly withdrawn and the marine deposits were simply allowed to collapse around and on top of these instruments to form a relatively impermeable seal. Any remaining open area at the collar of the drill hole was backfilled with drill cuttings (sand).

Absolute readings, sensitivity, response times and dissipation rate were compared between all instruments, in response to a staged sand surcharge of $10 \mathrm{~m}$ maximum height.

'Direct contact' pore water pressure measuring devices are not a new concept: proprietary push-in diaphragm piezometer instruments have been available for many years (Dunnicliff 1993). Dissipation testing from Dutch cone penetration test pore water pressure (CPTu) devices is another example of direct contact pore pressure measurement. These instruments, however, are typically pushed into the soil profile. Our field trials did not involve any 'pushing', because the piezometer is lowered into an open borehole and the natural marine muds are allowed to collapse around the VWP tip, enveloping and sealing the instrument in the ground.

More significantly, these trials were used to demonstrate that relevant geotechnical properties of the enveloping marine mud approximate those of the cement-bentonite grout proposed in the fully-grouted borehole method described in Mikkelsen and Green (2003).

The acceptance criteria we have considered for suitability of this technique are the undrained shear strength of the host soil, the soil particle size grading, the effective stress acting at the level of the piezometer instrument, and the permeability characteristics of the remoulded soil.

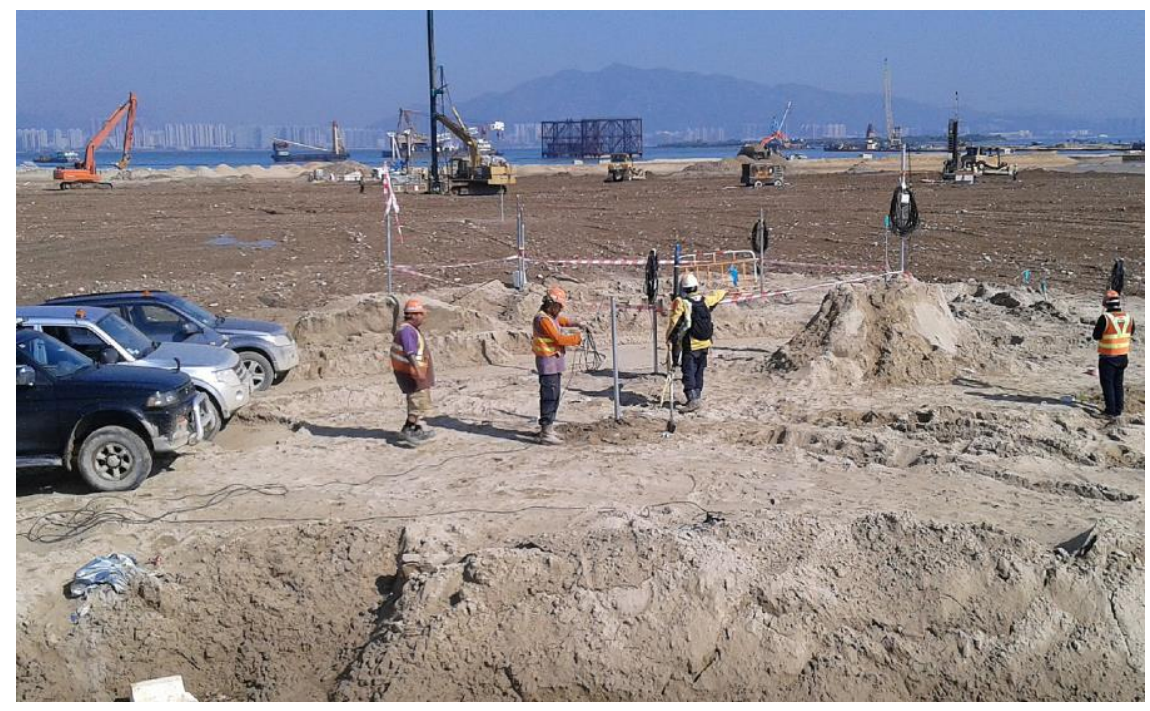

\section{Figure 1 Study area for the VWP trial installations}

\subsection{Project setting}

The Hong Kong-Zhuhai-Macao Bridge (HKZMB) project is a large sea crossing linking the Hong Kong Special Administrative Region with the mainland city of Zhuhai and the Macao Special Administrative Region. It consists of the main bridge, the Boundary Crossing Facility and link roads (Highways Department 2010).

The Boundary Crossing Facility Island as shown in Figure 2 is situated off the north coast of Lantau Island, Hong Kong. It will be a 150 hectare reclamation upon completion, constructed using hydraulically placed sand fill over the underlying soft, young marine deposits of the Hang Hau Formation (10 to $25 \mathrm{~m}$ thickness). It is a non-dredge design so that the marine deposits are left in situ and relatively undisturbed (Figure 3). 


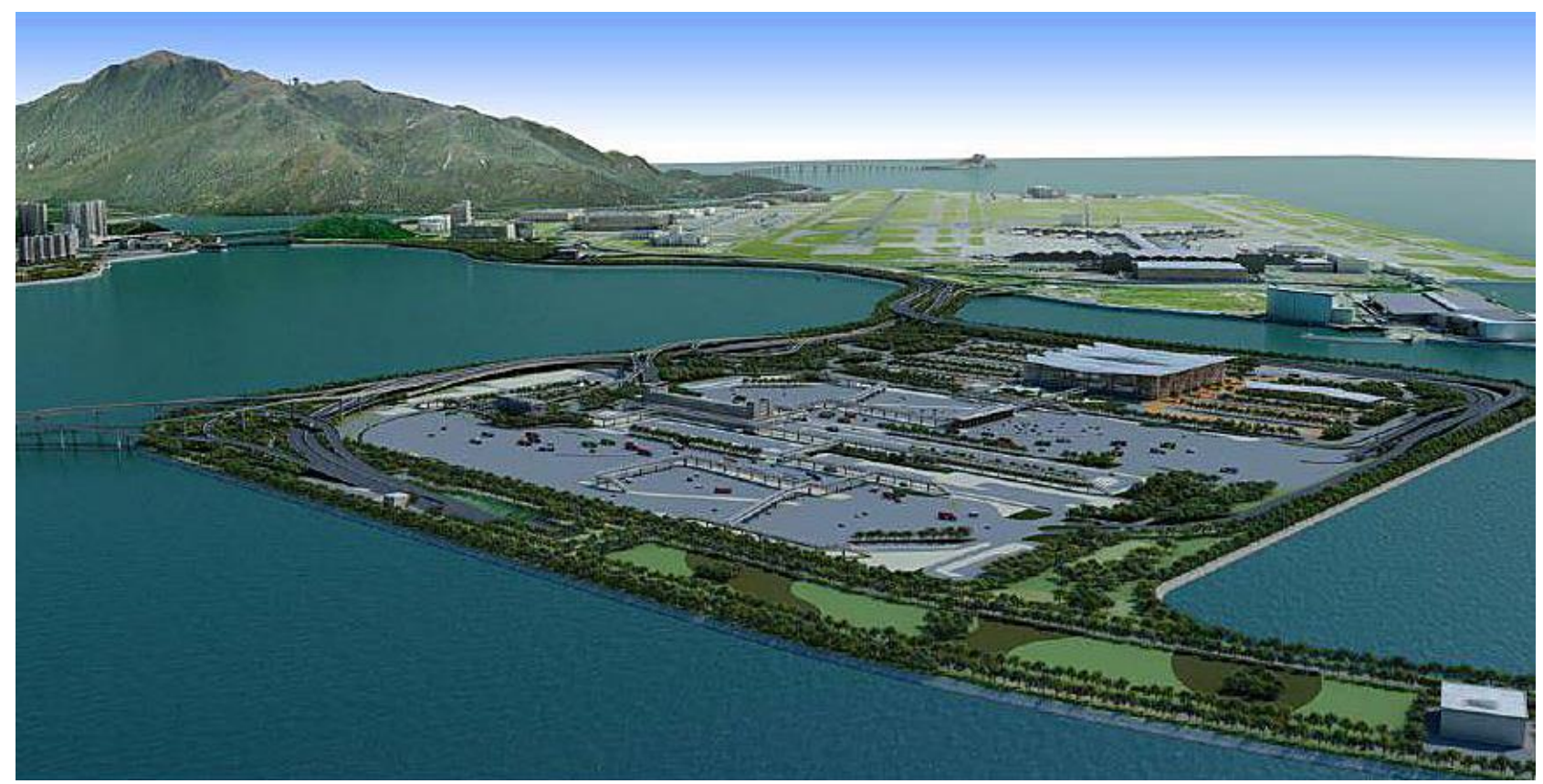

Figure 2 Artist's rendering of the completed Hong Kong Boundary Crossing Facilities (courtesy Highways Department of Hong Kong 2010)

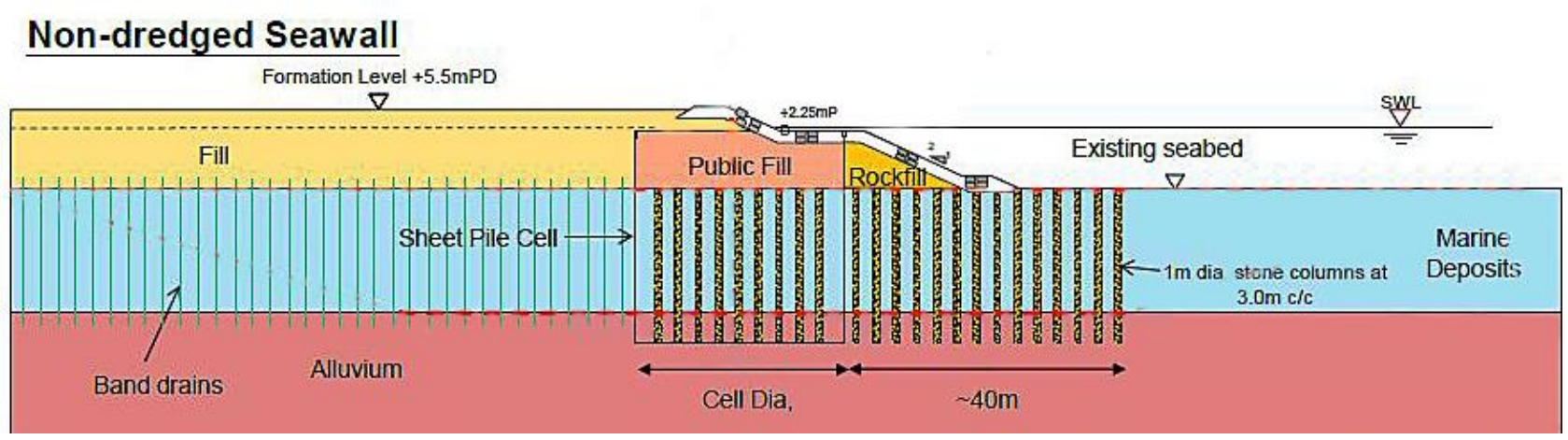

\section{Figure 3 Cross-section of the non-dredged seawall (courtesy Highways Department of Hong Kong 2010)}

Band drains (synthetic vertical wick drains) penetrate these marine deposits to expedite their drainage and consolidation. The reclamation sand fill is around $15 \mathrm{~m}$ thickness from seabed to finished level (5.5 mPD). An additional $10 \mathrm{~m}$ of sand surcharge is placed in stages and in phases above and across the finished level to expedite the consolidation process. The project is scheduled for completion during 2016.

\subsection{Previous work}

Fully-grouted-in VWP instruments (Figure 4(b)) have been previously recommended as an acceptable and even superior alternative to the conventional filter sand/bentonite seal response zones (Figure 4(a)) more commonly associated with Casagrande (traditional) standpipe piezometer installations (Mikkelsen and Green 2003). A range of acceptable grout designs and grout permeabilities were then proposed by Contreras et al. (2007) after laboratory testing, software modelling and field trials. Simeoni et al. (2011) further investigated the short response times required for the movement of hydraulic pressure through a cement-bentonite grout sample both in the laboratory (triaxial apparatus) and in the field in direct comparison with traditional Casagrande piezometer installations. The developments in diaphragm piezometer technology and installation techniques have been reviewed by Contreras et al. (2008) and others. The nude VWP installation technique (Figure 4(c)) replaces the backfill cement bentonite grout with collapsed natural soil. 


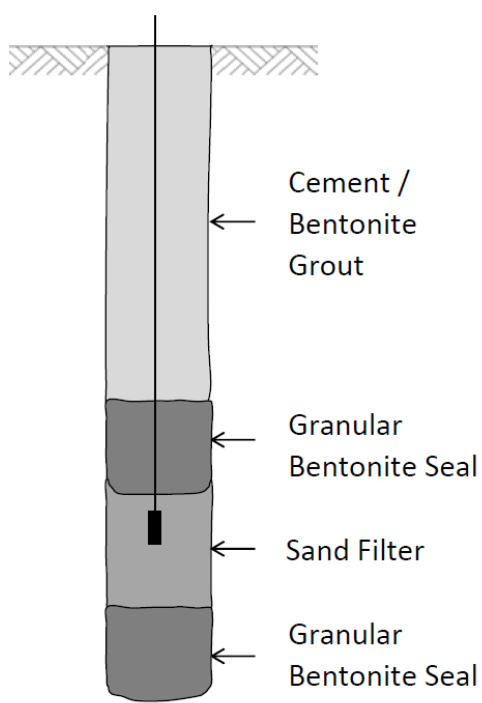

(a)

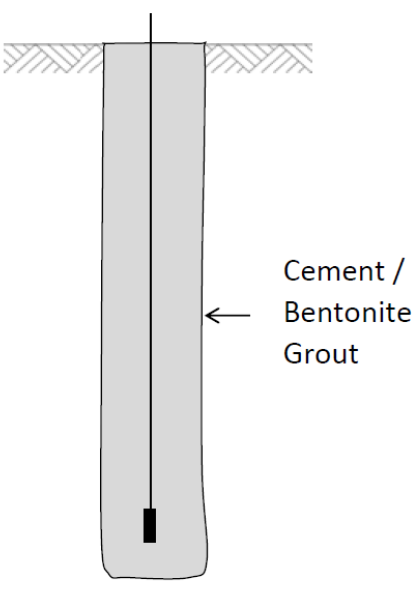

(b)

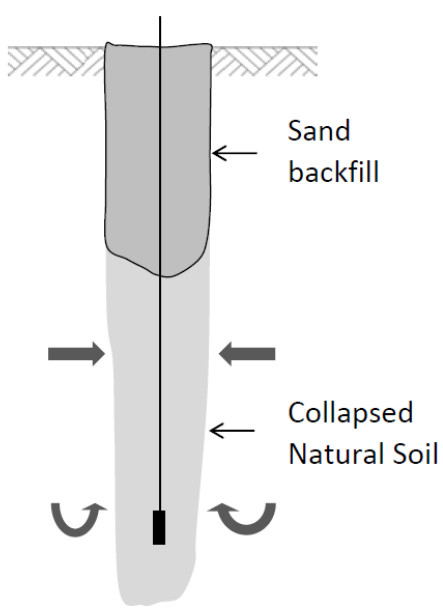

(c)

Figure 4 Sealing of piezometers in boreholes using (a) the traditional Casagrande detail; (b) fully-grouted technique; and (c) the nude technique for VWP instruments

\section{Site conditions}

\subsection{Geology}

The reclamation site is constructed on a sequence of superficial deposits comprising very soft to soft marine mud overlying alluvium deposits. These superficial deposits cover various weathered, older igneous and sedimentary rocks of complex geological structure. A summary of the solid and superficial geology based on Hong Kong Geological Survey (2002) and Hong Kong Geology Guide Book (Geotechnical Engineering Office, 2008) is presented in Table 1.

Table 1 Summary of solid geology and superficial stratigraphy of the study area

\begin{tabular}{|c|c|c|c|c|}
\hline \multicolumn{2}{|c|}{$\begin{array}{l}\text { Stratigraphic divisions } \\
\text { (geologic age in M.Y.A.) }\end{array}$} & $\begin{array}{l}\text { Lithostrati- } \\
\text { graphy }\end{array}$ & $\begin{array}{l}\text { Genetic } \\
\text { classification }\end{array}$ & Principal materials \\
\hline \multicolumn{5}{|c|}{ Superficial deposits } \\
\hline $\begin{array}{l}\text { Quaternary } \\
(1.80-0)\end{array}$ & $\begin{array}{c}\text { Holocene } \\
(0.01-0) \\
\text { Pleistocene } \\
(1.80-0.01)\end{array}$ & $\begin{array}{l}\text { Hang Hau } \\
\text { Formation } \\
\text { Chek Lap Kok } \\
\text { Formation }\end{array}$ & $\begin{array}{l}\text { Marine mud } \\
\text { Marine sand } \\
\text { Alluvium }\end{array}$ & $\begin{array}{l}\text { Soft to very soft mud, some sand } \\
\text { Sand, some gravel and mud } \\
\text { Clay, silt, sand and gravel }\end{array}$ \\
\hline \multicolumn{5}{|c|}{ Major intrusive rocks } \\
\hline $\begin{array}{l}\text { Mesozoic } \\
(248-65)\end{array}$ & $\begin{array}{l}\text { Jurassic (206-144) } \\
\text { Cretaceous (144-65) }\end{array}$ & \multicolumn{3}{|c|}{$\begin{array}{l}\text { Fine-grained granite; fine- to medium-grained granite; medium- } \\
\text { grained granite. (Locally metamorphosed) }\end{array}$} \\
\hline \multicolumn{5}{|c|}{ Minor intrusive rocks } \\
\hline \multicolumn{2}{|c|}{ Mesozoic (248-65) } & \multicolumn{3}{|c|}{ Feldsparphyric and Quartzphyric Rhyolite } \\
\hline \multicolumn{5}{|c|}{ Sedimentary rocks } \\
\hline
\end{tabular}


Mesozoic

(248-65)

Jurassic (206-144)

Meta-siltstone with meta-sandstone

The subject piezometer instruments were placed in the marine muds of the Hang Hau Formation. This soft marine mud forming the sea floor is classified as the Quaternary Holocene Hang Hau Formation (QHH) and was deposited during the Holocene period of Quaternary era. The typical thickness of the marine deposits across the study area ranges from 10-20 m with areas up to $25 \mathrm{~m}$ in thickness (Hong Kong Geological Survey 2002). The marine deposit layer is fairly uniform and blankets most of the sea bed across the northern Lantau offshore area (Geotechnical Engineering Office 1994). The base of the Hang Hau Deposits lies unconformably on an erosional surface of the Chek Lap Kok Formation. These are alluvium deposits of Pleistocene age. They are lithologically more variable and comprise interbedded soils of a full range from clay to cobbles; with clays and silts of the deposits tending to be firmer than the marine muds (Hong Kong Geological Survey 2002).

\subsection{Soil properties and geotechnical conditions of the Hang Hau marine deposit}

\subsubsection{Particle size distribution}

The marine deposit comprises soft, dark greenish grey, silt/clay with occasionally some shell fragments. Pockets of marine sand and gravel are locally present throughout the strata. Particle size distributions of samples from the marine deposit are shown in Figure 5.

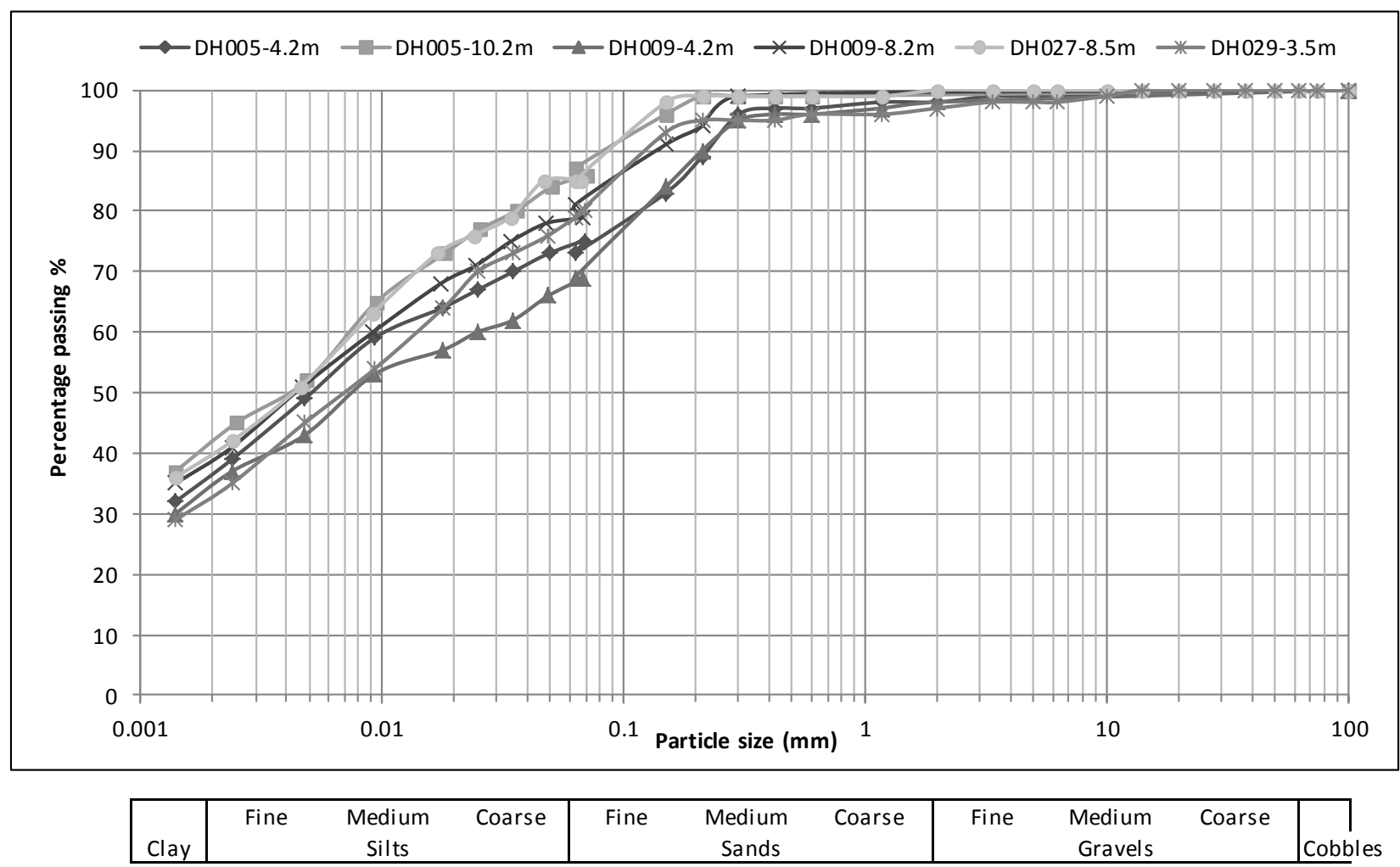

Figure 5 Particle size distribution of marine mud in the study area

\subsubsection{Undrained shear strength}

Undrained shear strengths (Su) for the undisturbed and unconsolidated marine mud are reported by Hong Kong Geological Survey (2002) to range from 3-20 kPa. Values obtained from laboratory tests on samples recovered from marine ground investigations are in agreement with these published values. Maximum shear strengths of up to $39 \mathrm{kPa}$ were measured using situ vane shear testing (VST) as shown in Figure 6. 
Undrained shear strengths characteristically increase with the depth, and the study piezometers were placed at an elevation of -10 to $-15 \mathrm{mPD}$ where the Su range was 15 to $20 \mathrm{kPa}$.

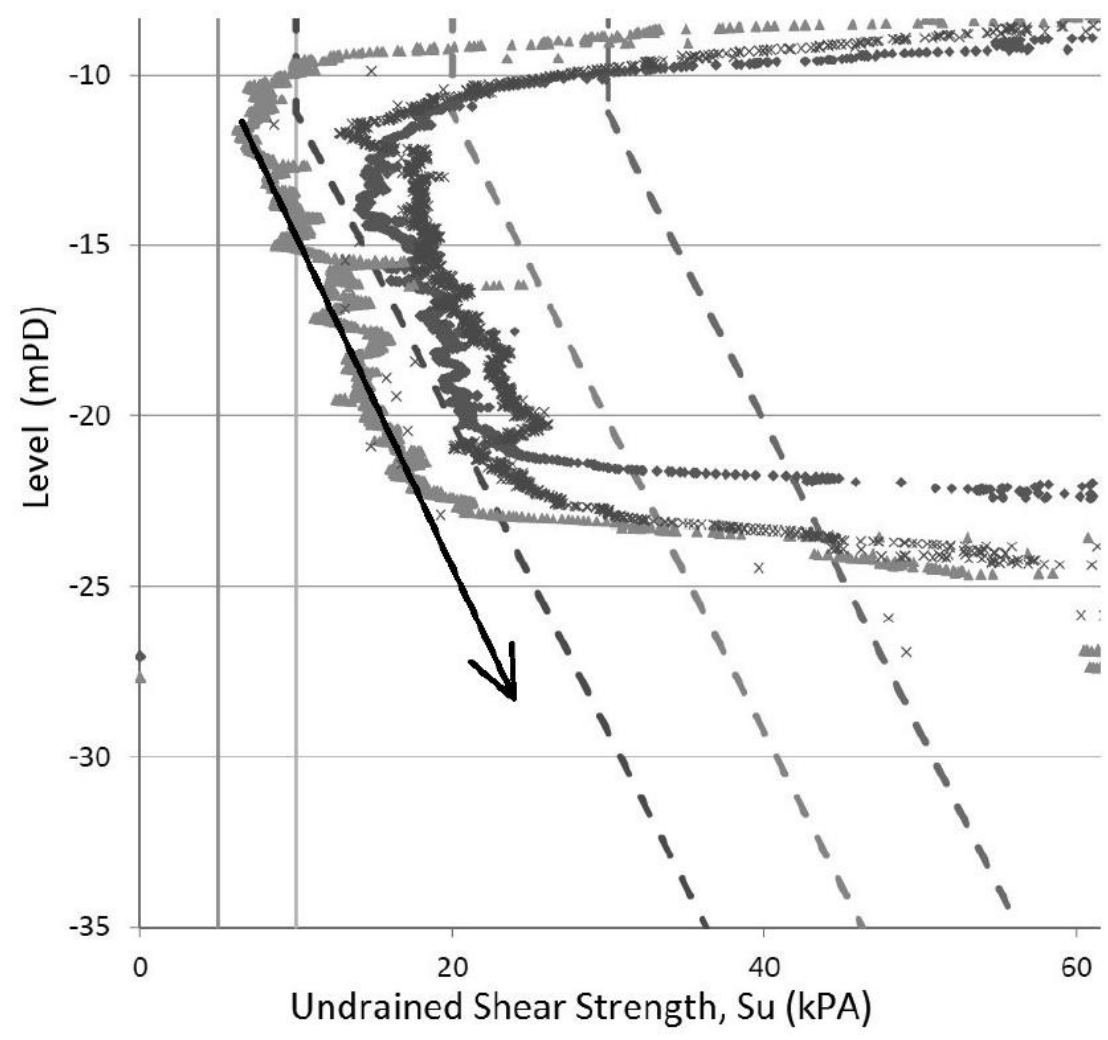

Figure 6 Undrained shear strength gradient for the Hang Hau marine deposits (courtesy of Fugro, 2010)

\subsubsection{Permeability}

Recommended borehole grouts described by Mikkelsen (2002) have a range of permeability k-values between $10^{-10}$ to $10^{-7} \mathrm{~m} / \mathrm{s}$. In situ and laboratory permeability test results for the local marine muds are reported in Fugro (2010) and Kwong (1997, and are a similar range of permeability values of between $10^{-9}$ to $10^{-7} \mathrm{~m} / \mathrm{s}$ (Table 2).

Further research by Contreras et al. (2008) demonstrated a broader acceptable range of borehole sealing grout permeabilities - described as the ratio of the permeability of grout and the permeability of soil ( $\left.\mathrm{K}_{\text {grout }} / \mathrm{K}_{\text {soil }}\right)$. Their findings were that permeability of the grout mix can be up to three orders of magnitude greater than the permeability of the surrounding ground without introducing significant error. The permeability of the remoulded marine muds are considered to fall within the range of acceptable grout permeabilities described above. It is therefore practical to replace the borehole backfill grout with the remoulded marine mud.

Table 2 Geotechnical properties of marine mud in the north Lantau offshore area

\begin{tabular}{cccc}
\hline $\begin{array}{c}\text { Geotechnical } \\
\text { properties }\end{array}$ & Unit & $\begin{array}{c}\text { Fugro Geotechnical } \\
\text { Services Ltd (2010) }\end{array}$ & Kwong (1997) \\
\hline k & $(\mathrm{m} / \mathrm{s})$ & $10^{-8}-10^{-7}$ & $10^{-9}-10^{-7}$ \\
Unit weight & $\left(\mathrm{kN} / \mathrm{m}^{3}\right)$ & $13-16$ & $13-20$ \\
Su & $(\mathrm{kPa})$ & $5.2-22.9$ & $<3-20$ \\
LL & $(\%)$ & $50-0$ & $55-100$
\end{tabular}




\begin{tabular}{lllc}
$\mathrm{PL}$ & $(\%)$ & $25-45$ & - \\
$\mathrm{PI}$ & $(\%)$ & $15-50$ & $20-70$ \\
\hline
\end{tabular}

\subsubsection{Effective stress}

Effective stress is a fundamental control over the strength of a soil and any change in its volume (Das 2002). The suitability of the nude installation technique relies on the collapse and remoulding of the soil. The effective stress acting at the level of the VWP sensors at the time of installation in the study area ranged from 180 to $250 \mathrm{kPa}$, depending on the thickness of reclamation fill and the thickness of the marine deposit layer. The unit weights used for the sand fill/surcharge and marine clay are 19 and $14 \mathrm{kN} / \mathrm{m}^{3}$ respectively (The Government of the Hong Kong Special Administrative Region 2002).

\subsection{Limitations and applicability of the nude installation technique}

The installation technique relies on the collapse and remoulding of natural ground around the VWP sensor upon withdrawal of drilling support casing.

The first limitation we propose is that there should be sufficient effective stress through the soil to stimulate collapse of the borehole wall material. Secondly, there should be a predominantly clay and silt fraction particle size in the host soil to assist with remoulding and the remoulded permeability should fall within the acceptable range for grouts (a permeability ratio of 1,000 or less), as described by Contreras et al (2008). This permeability ratio is more appropriately expressed for a nude VWP installation as the ratio ( $\left.\mathrm{K}_{\text {remoulded soil }} / \mathrm{K}_{\text {soil }}\right)$.

The third limitation we propose is that the undrained shear strength of the host soil cannot be too high, such that the soils surrounding the instrument are able to close in with the aid of vertical pressure such as overburden or surcharge, depending on the shear strength of the soil. The piezometers in this study were placed at depths of -10 to $-15 \mathrm{mPD}$ - where the ranges of values for Su were an acceptable $15-20 \mathrm{kPa}$.

Nude VWP installations are therefore suitable for soft, fine grained soils that are subject to sufficient effective stress to stimulate movement and remoulding in the borehole above the instrument. The natural soil forms an impermeable seal upon remoulding; effectively acting as a replacement for grout.

\section{$3 \quad$ Full-scale field trials}

Full-scale field trials proceeded at two instrument cluster sites on the sand reclamation (Sites 35 and 46). Installations commenced in October 2014 and continued through to mid-2015. Monitoring was performed by automatic logging.

\subsection{Method of installation}

Drill holes of $96 \mathrm{~mm}$ diameter $(\mathrm{HQ})$ were sunk using conventional rotary drilling techniques with water as a flushing medium. A single VWP was placed in each drill hole. It is noted that it would also be possible to install multiple VWPs in a single drill hole as described by Yungwirth et al. (2013).

Prior to the installation, metre increments were marked on the piezometer cable to ensure proper installation at the required depth. The filter tip was saturated with clean fresh water to prevent air bubbles forming inside the instrument, and a frequency and temperature reading were taken to ensure proper functioning. A $1 \mathrm{~m}$ length of $19 \mathrm{~mm}$ diameter galvanised iron water pipe was passed over the VWP cable and taped in place above the sensor tip to provide ballast to stabilise the instrument when the drilling casing was withdrawn. The circular form and narrow diameter of this hollow rod maximised the potential for proper sealing of the VWP instrument (Figure 7). The filter tips were not inverted for these trials. 


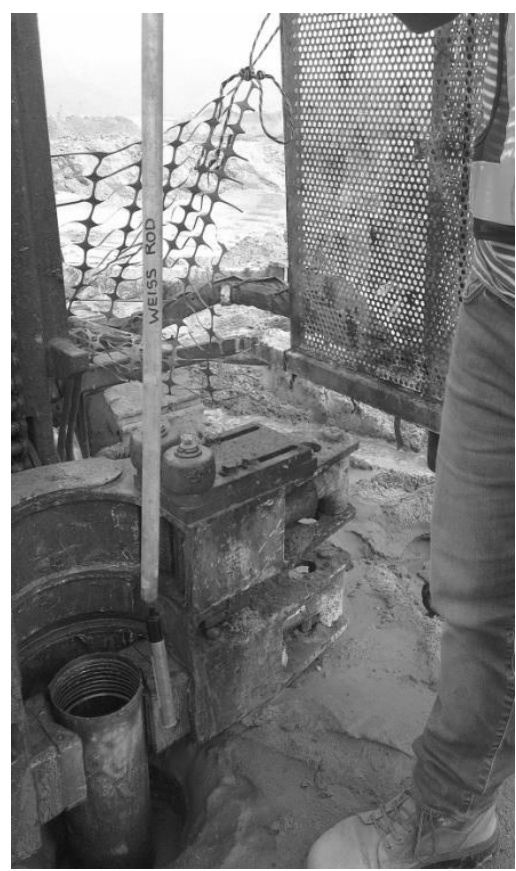

Figure 7 Ballasting pipe and nude VWP about to be lowered down the borehole, Site 35

The sensor was then lowered into the drill hole and once the installation depth was reached, another set of readings were taken to verify the instrument was properly adapting to the water pressures and temperature changes. The drill casing was then carefully removed without rotation, allowing the surrounding saturated, soft, fine grained soils to collapse around and above the instrument, providing the required seal. Any remaining open area at the collar of the drill hole was backfilled with sand and a final set of readings were taken to ensure proper functioning.

The nude VWP was installed approximately three metres from a traditional installation (Figure 8) and at depths of approximately 18 to 23 metres below existing ground level as summarised in Table 3 . Each nude installation took less than 1.5 hours from the commencement of drilling to final operational check of the installed instrument. Upon installation of the nude VWPs and withdrawal of casing, the collapsed natural soil was observed to rise inside the borehole and penetrate into the sand fill layer. These observations confirmed that remoulding of soil was occurring around and above the piezometer tips.

\section{Table 3 Installation summary for trial VWP instruments installed on the project}

\begin{tabular}{ccc|ccc}
\hline Site 35 & $\begin{array}{c}\text { Depth } \\
\text { (mPD) }\end{array}$ & $\begin{array}{c}\text { Depth bgl on } \\
\text { installation } \\
(\mathbf{m})\end{array}$ & Site 46 & $\begin{array}{c}\text { Depth } \\
\text { (mPD) }\end{array}$ & $\begin{array}{c}\text { Depth bgl on } \\
\text { installation } \\
(\mathbf{m})\end{array}$ \\
\hline Traditional 1 & -16.39 & 19.50 & Traditional 3 & -15.00 & 20.50 \\
Traditional 2 & -14.21 & 17.50 & Nude 3 & -15.00 & 22.29 \\
Nude 1 & -14.40 & 18.00 & & & \\
Nude 2 & -14.40 & 18.00 & & & \\
\hline
\end{tabular}




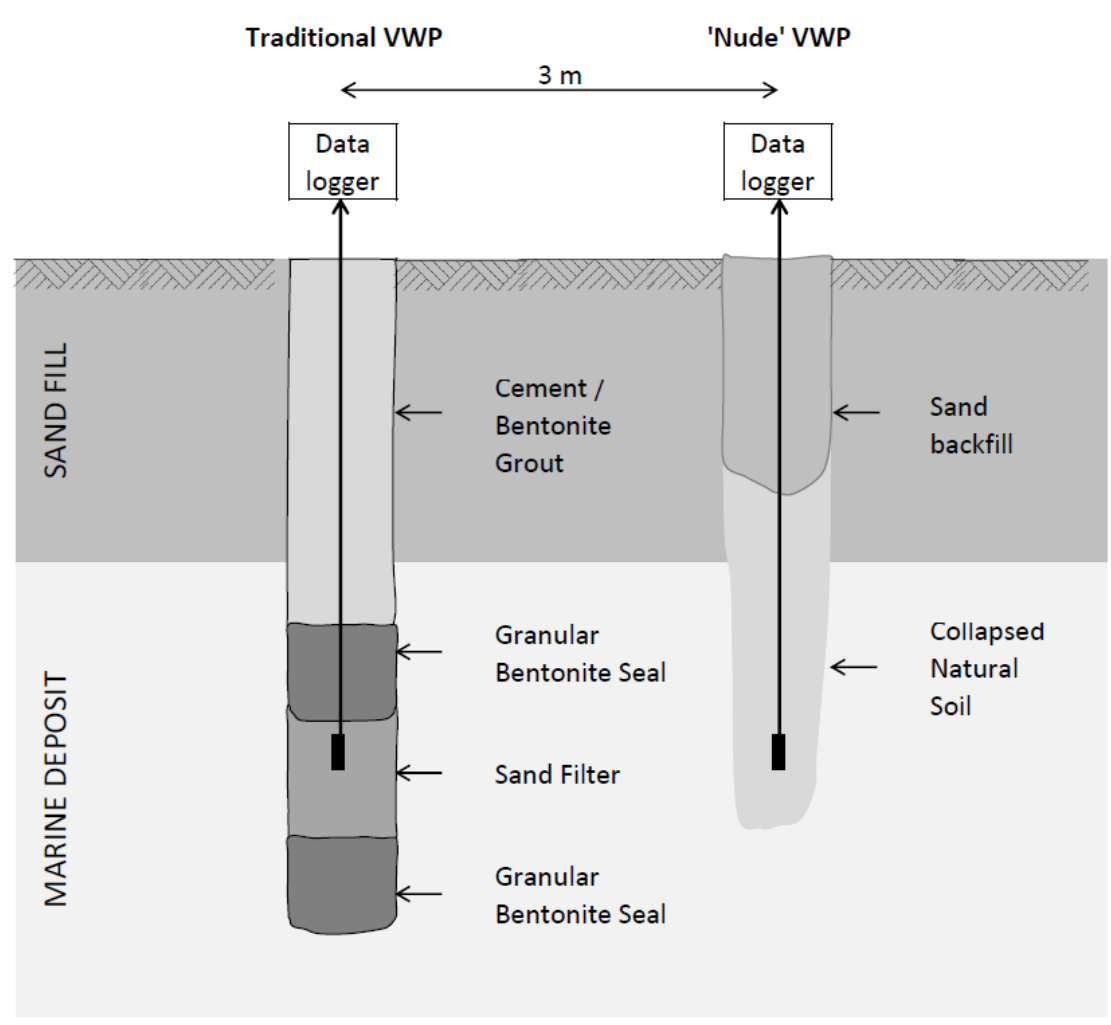

Figure 8 Cross-section of a traditional and a nude VWP installation

\section{$3.2 \quad$ Equipment}

\subsubsection{Vibrating wire piezometer}

Standard borehole vibrating wire piezometers were used. These instruments are designed to measure pore water pressures of up to $700 \mathrm{kPa}$ and are equipped with a thermistor for temperature compensation purposes. The tips are made of stainless steel and contain a steel wire that is attached to the housing on one side and a diaphragm on the other side. The diaphragm reacts to minuscule movements of water $\left(10^{-7}\right.$ to $10^{-6} \mathrm{~m}^{3}$, Yungwirth et al. 2013), changing the tension in the wire. A readout device sends an electrical signal to the electromagnetic coil to excite the wire to make it vibrate at its natural frequency. This signal is transmitted back to the readout device in a frequency reading which can be used to calculate hydraulic pressure and pressure changes in engineering units.

\subsubsection{Vibrating wire readout}

A vibrating wire readout unit was used to check the sensor functionality before, during and after the installation. The device is not capable of storing readings; therefore, readings have to be manually recorded.

\subsubsection{Vibrating wire miniloggers}

Single channel VWP miniloggers were installed to monitor the instrument readings. The loggers were battery powered and waterproof sealed to prevent damage during monitoring.

\subsection{Data acquisition}

The logger boxes for all instruments were set to take readings at one hour intervals and data was retrieved approximately once a week by connecting a serial cable to the logger and manually downloading the data onto a portable computer. Once data was retrieved, the logger memory was cleared to avoid reaching the maximum storage capacity of the logger. 
Data is compiled and inserted into a monitoring record spreadsheet to calculate the pressures of each VWP and plot the graph for further interpretation.

\subsection{Results at Site 35}

At Site 35, two nude VWP and two traditional VWP installations were monitored. All VWP instruments remained functional throughout the five months of monitoring, with two months of background readings attained prior to commencement of surcharging above finished design level.

The long term monitoring results for Site 35 are presented in Figure 9 as piezometric head and height of surcharge against time. For the purposes of presentation, almost two months of stable pre-surcharge monitoring data have been removed - during which time the drainage of the reclamation was observed as a depressurisation gradient. The record in Figure 9 presents one week of readings pre-surcharge, and is normalised by setting all piezometer instrument readings to a zero piezometric pressure level on 17 January 2015.

Surcharge height was lifted in stages, with a $1 \mathrm{~m}$ lift on 24 January 2015 recorded as a response of $15.0 \mathrm{kPa}$ in all VWP instruments. Another $1.5 \mathrm{~m}$ surcharge height was added on 5 March 2015 - and this was recorded as an additional response of $22.5 \mathrm{kPa}$ in all VWP instruments. Minor breaks in the monitoring record are the consequence of inconsistent battery life in the mini loggers.

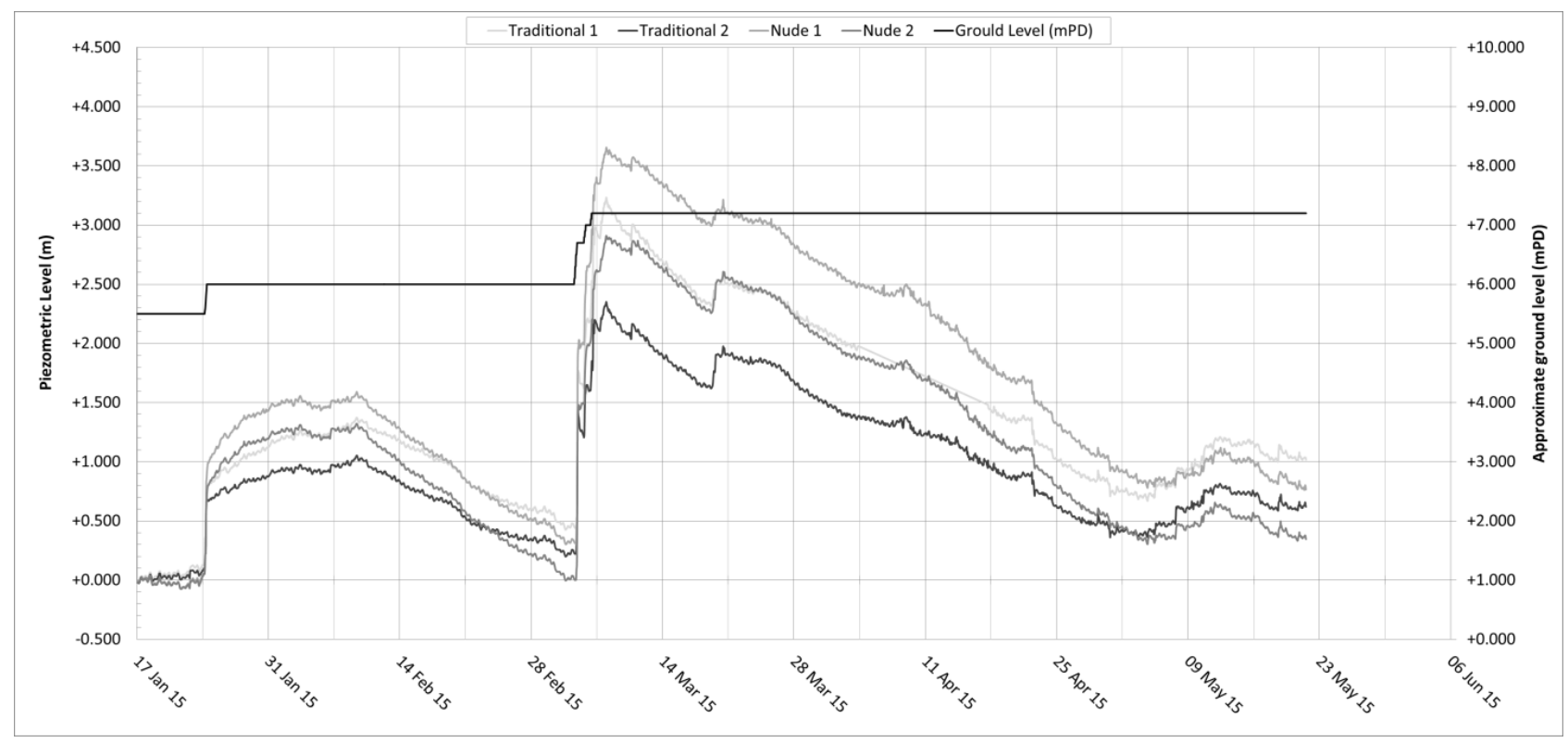

\section{Figure 9 Normalised monitoring results against surcharging level for Site 35}

All instruments were installed at similar depths; however, the stable, initial piezometric readings were observed to be significantly higher in the 'Nude 1' and 'Nude 2' instruments: up to nine metres greater when compared with the conventionally installed VWPs. After surcharge was added, this nine metre difference decreased and stabilised to around seven metres in head and was sustained for the duration of the record. This sustained elevated head demonstrated that the pore pressure was not dissipating along the borehole in the nude installations. The authors conclude that the ballasting pipe (Figure 7) held the nude VWP installation at its correct depth - and the elevated head may be explained as due to variations in separation distance from the vertical drains.

Figure 10 presents the full record of piezometric pressures observed from all four instruments at Site 35. These results record one month of pre-surcharge readings followed by four months of readings during staged sand surcharge. The dissipation gradients, pressure changes upon application of surcharge are in good agreement for all instruments. All readings were subsequently normalised for presentation purposes. 


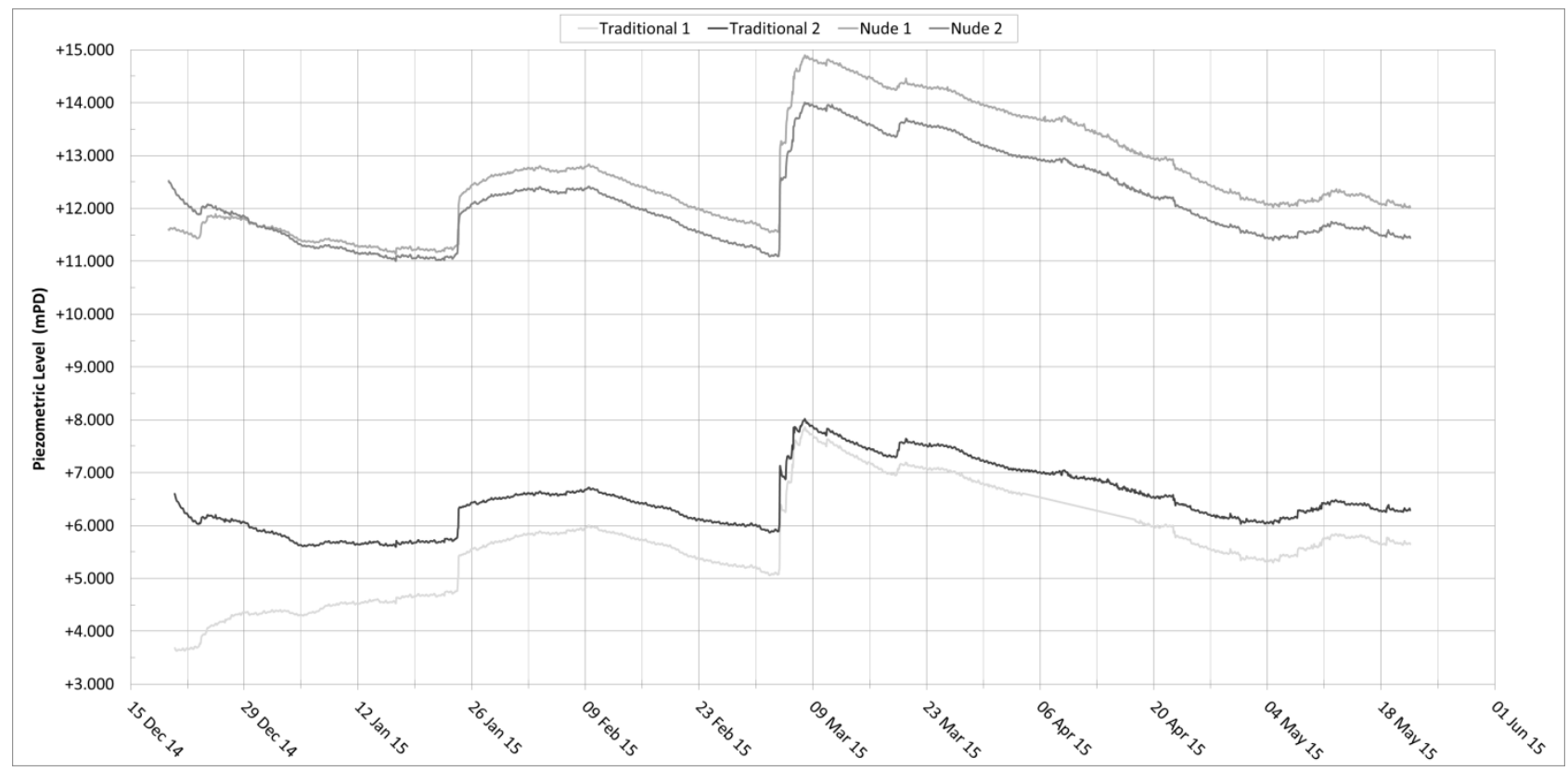

Figure 10 Five-month monitoring results for Site 35

Major observations from the results from Site 35 presented in Figure 9 and Figure 10 are:

Absolute readings: The 'Nude 1' VWP installation responded to a $1 \mathrm{~m}$ sand surcharge loading on 24 January with the highest recorded change in pore water pressures. This increase in pore pressure was $12.0 \mathrm{kPa}$ within hours of surcharge, and climbed to $16.4 \mathrm{kPa}$ on 9 February 2015. This response characteristic was repeated with the same instrument when an additional $1.8 \mathrm{~m}$ surcharge placed over the period 5-7 March 2015 returned a peak increase in pore pressure of $32.9 \mathrm{kPa}$ on 8 March 2015. It was also the deepest instrument and furthest removed from the overlying relatively free draining sand. The 'Nude 2' VWP installation was at a similar depth, and provided the second highest responses of $11.1 \mathrm{kPa}(1 \mathrm{~m}$ surcharge, 9 February), and $290 \mathrm{kPa}$ (1.8 $\mathrm{m}$ surcharge, $8 \mathrm{March}$ ). Responses in all VWP instruments were almost immediate, and then continued to rise over an extended period of time. This was most likely due to surcharging that continued in the surrounding area.

Response time(s): The times to respond to changes in surcharge are very similar in all VWP instruments, occurring almost immediately upon placement of the surcharge lifts. Following a $1 \mathrm{~m}$ surcharge placement on 24 January 2015, there was a hold to additional surcharging for two months. The period 24 January to 10 February 2015 also show very similar piezometer responses to distal surcharging. The piezometer response kick is most effectively observed during the 5-7 March surcharge episode, when an additional $1.8 \mathrm{~m}$ of sand surcharge was added.

Dissipation: The dissipation response overprints the rise in pore water pressures when surcharge was added. This response was likely controlled by individual VWPs proximity to vertical band drains set out on a $2 \mathrm{~m}$ spacing grid, and some differences in installation elevation between VWP instruments, with shallower instruments closer to the sand forming horizontal drainage and the reclamation. From 11 February to 5 March, the natural and induced drainage influence of vertical bands drains is observed in the depressurisation characteristics of the piezometers. Hold points in the surcharge allowed the dissipation or drainage of pore water to be observed between nude and traditional VWP installations. These were similar in gradient, with the two nude installations reporting slightly faster dissipation characteristics.

Tidal influences: A very high tide experienced on 18 February (Hong Kong Observatory 2015) served as a marker tide, and resulted in a similar peak in the VWP instruments installed in marine mud at Site 35 . The lag time before this tide showed in the piezometric records was 13 hours. All normalised VWP results (showing diurnal tide peaks and troughs and removing background dissipation signature) are presented as Figure 11. 


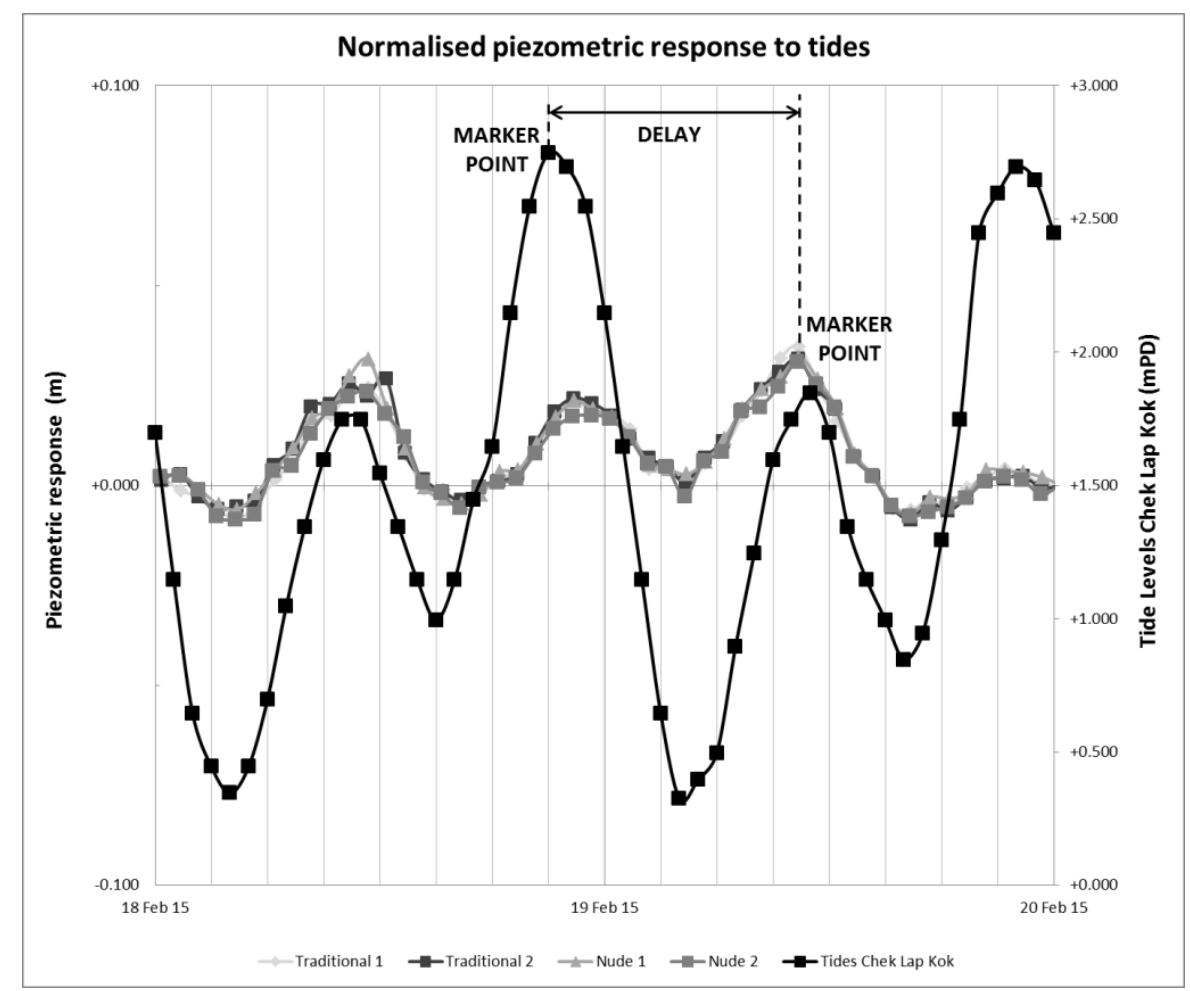

\section{Figure 11 Tidal influences for Site 35}

\subsection{Results at Site 46}

At Site 46, one nude VWP and one traditional VWP installation were installed at similar depths in marine mud (Table 3) and monitored from October 2014. The area was not subject to additional sand surcharge for six months, and pore pressure dissipation was observed in both instruments during that time. The slightly faster rate of dissipation observed in the 'Nude 3' VWP is most likely due to its proximity to vertical drains, as presented in the long term monitoring record (Figure 12).

During most of April 2015, additional surcharge of approximately $3.5 \mathrm{~m}$ height was gradually placed over Site 46. This resulted in pore water pressure increases of $57.1 \mathrm{kPa}$ in the conventional installed VWP) and $54.9 \mathrm{kPa}$ in the 'Nude 3' VWP).

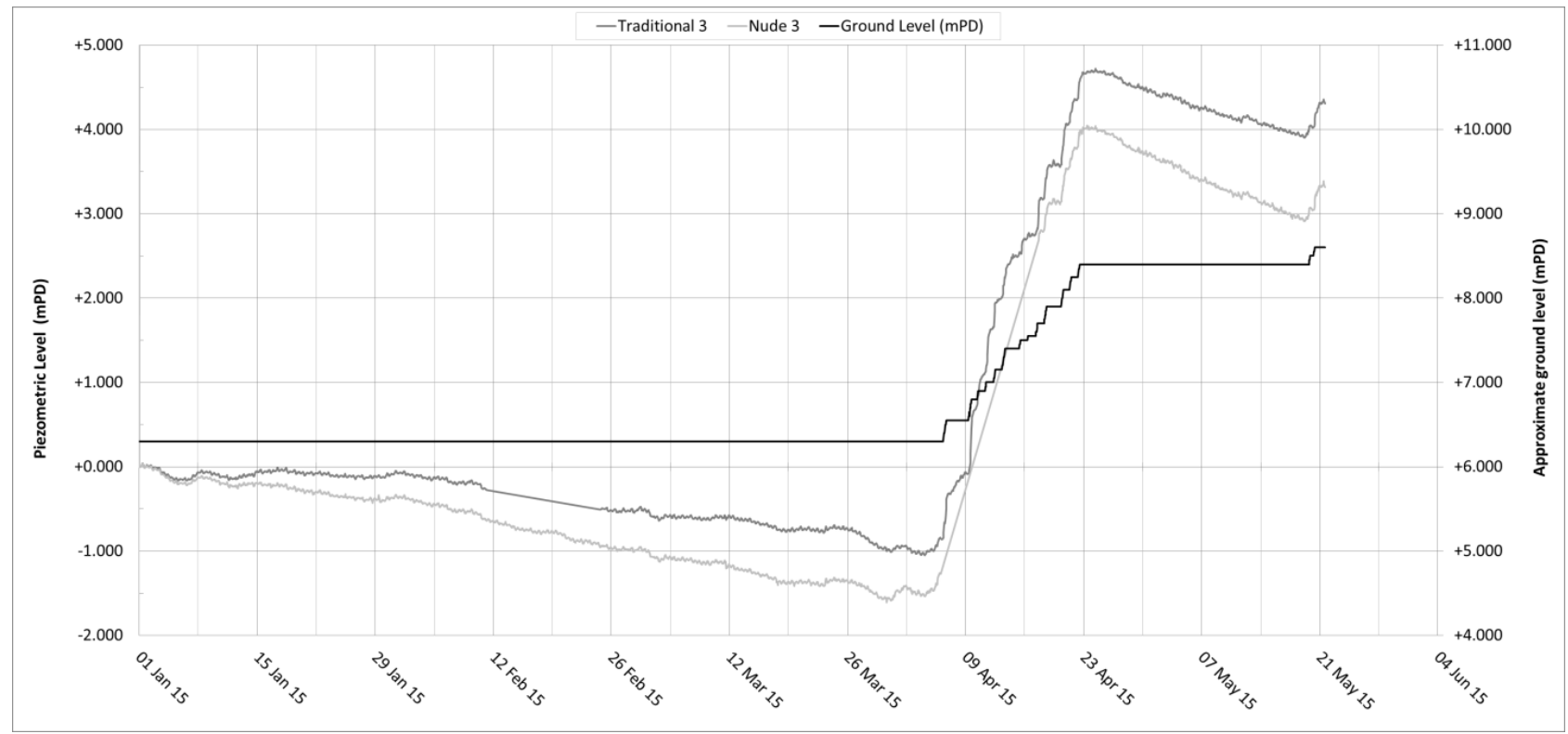

Figure 12 Normalised monitoring results against surcharging level for Site 46 
Major observations from the results from Site 46 presented in Figures 12 and 13 are:

Absolute readings: The 'Nude 3' VWP installation responded to a $3.5 \mathrm{~m}$ sand surcharge loading during April 2015 with an ultimate increase in pore pressure of $54.9 \mathrm{kPa}$ by 23 April 2015. The response from the conventionally installed VWP for the same surcharge episode was $57.1 \mathrm{kPa}$ and peaked on 24 April 2015.

Response time(s): The timing of the response from both VWP instruments is almost identical; the surcharge episode occurred over the period the 5 April to 24 April 2015.

Dissipation: Dissipation over the period 23 October 2014 to 5 April 2015 was recorded at $36 \mathrm{kPa}$ in the 'Nude $3^{\prime}$ instrument, and $17.1 \mathrm{kPa}$ in the conventionally installed VWP. This slightly faster dissipation response observed in the 'Nude 3' VWP instrument is most likely due to its proximity to vertical band drains set out on a $2 \mathrm{~m}$ spacing grid. Dissipation gradients were similar given the duration of monitoring.

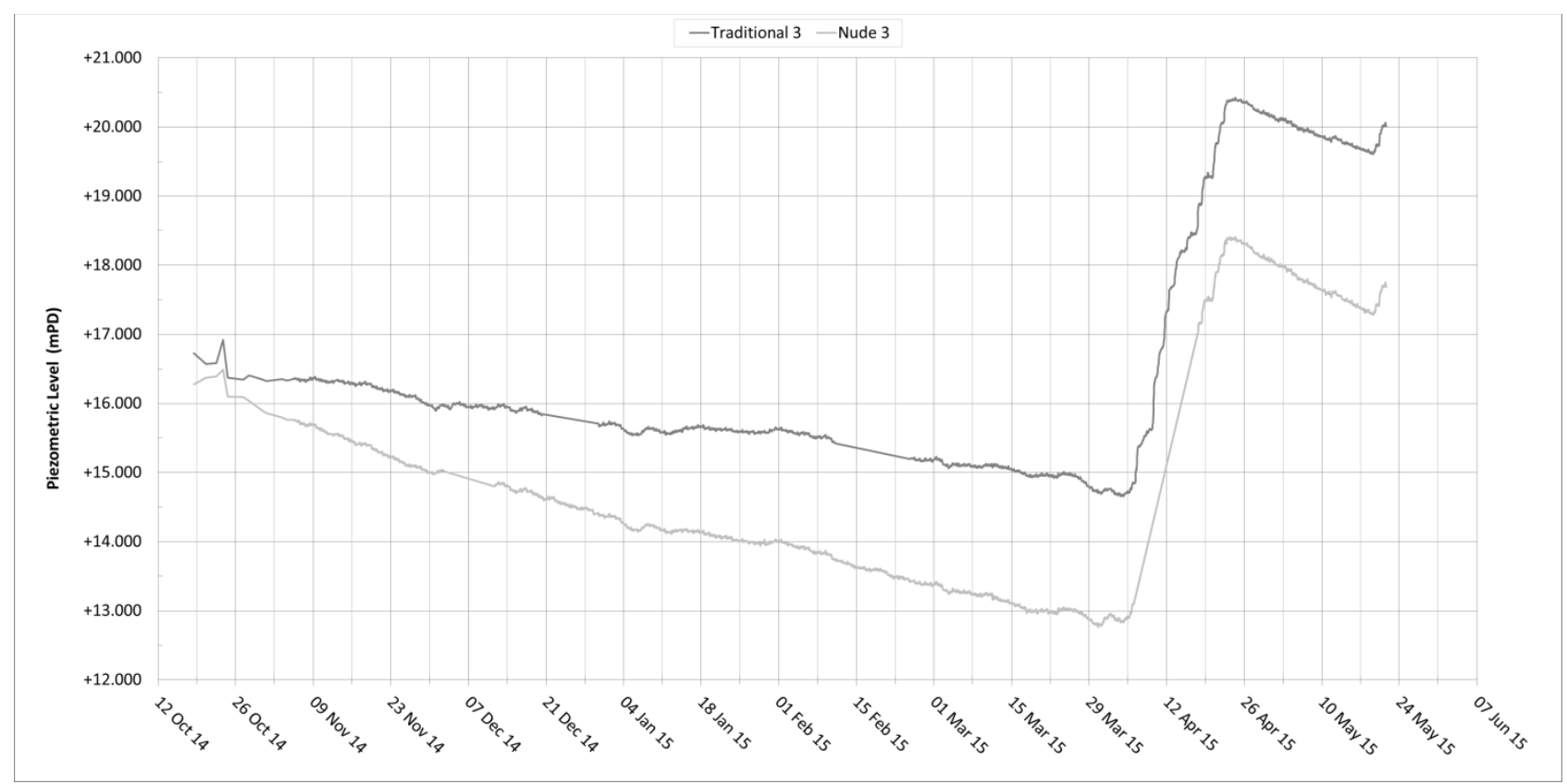

\section{Figure 13 Seven-month monitoring results for Site 46}

\section{Conclusion}

This paper presents a discussion on the traditional installation method versus the proposed nude VWP installation method, including the installation procedure and theoretical background. The nude VW piezometer installation is proposed as a suitable alternative to the fully-grouted borehole technique in certain ground conditions where the borehole seal is provided by the collapse of natural soil. We have considered undrained shear strength, grading and effective stress acting at the level of the instrument to be appropriate benchmarks. Our findings are based on field performance observations of nude and traditional VWP installations at two sites on one major reclamation project in Hong Kong. There was good agreement between pore pressures measured with the traditional VWP installations and the nude VWP installations.

The nude installation technique relies on the collapse and remoulding of natural ground around the VWP sensor upon withdrawal of the drilling support casing, and there should be:

- Sufficient effective stress acting through the soil to stimulate collapse of borehole wall material. A range of effective stress of 180-250 kPa acting on the instrument was found to be acceptable.

- A predominantly clay and silt fraction in the host soil; and the remoulded permeability should fall within an acceptable range, with a permeability ratio of 1,000 or less for the ratio $\left(\mathrm{K}_{\text {remoulded soil }} / \mathrm{K}_{\text {soil }}\right)$, after Contreras et al. (2008). 
- The undrained shear strength of the host soil cannot be too high, such that the soils surrounding the instrument are able to collapse with the aid of vertical pressure. The range of values for Su was $15-20 \mathrm{kPa}$ in the study area.

The range of acceptable grout permeabilities used in the fully-grouted method and the permeability of the Hang Hau marine muds are compared and considered similar; therefore, one material should be interchangeable for the other material to seal a borehole.

The nude VWP installation is simplified by the absence of engineered grout, sand filters and bentonite seals. This, combined with the ballast pipe reduces the possibility for errors during installation and reduces the time necessary for installation. It is an economical and accurate procedure that may be used to measure pore water pressures in soft soils. Multiple installations in one hole are also possible.

\section{Acknowledgement}

The support provided by Fugro Geotechnical Services Ltd and the Durham Geo Slope Indicator Company is gratefully acknowledged. The authors also thank the Hong Kong Highways Department, Arup and the China Harbour Engineering Company for allowing full-scale tests to be performed on the project site. Thanks also to James Polson of Lovett Ltd and his team for providing the necessary drilling support. The information and views set out in this paper have been prepared in good faith by the authors on the basis of information available without any independent verification. Opinions expressed are solely those of the authors and do not necessarily reflect the opinions of others or any organisation. Readers are responsible for assessing the relevance and accuracy of the content of this publication.

\section{References}

Contreras, IA, Grosser, AT \& VerStrate, RH 2007, 'The use of the fully-grouted method for piezometer installation', in J DiMaggio \& P Osborn (eds), Proceedings of the Seventh International Symposium on Field Measurements in Geomechanics, American Society of Civil Engineers, Reston, VA, pp. 1-20.

Contreras, IA, Grosser, AT \& VerStrate, RH 2008, 'The use of the fully-grouted method for piezometer installation, Geotechnical News, June, pp. 30-37.

Das, BM 2002, Principles of Geotechnical Engineering, 5th edn, Brooks/Cole Publishing, Pacific Grove, CA.

Dunnicliff, J 1993, Geotechnical instrumentation for monitoring field performance, Wiley-Interscience, New York.

Fugro 2010, Fugro Geotechnical Services Ltd, Contract No. HY/2009/23, Ground Investigation Works for the Hong Kong Boundary Crossing Facilities, Final Factual Drill Hole Fieldwork Report, 8 volumes, GIU: 52156 to 52163.

Geotechnical Engineering Office 1994, Tung Chung: solid and superficial geology, map, Hong Kong Geological Survey, Hong Kong.

Geotechnical Engineering Office 1997, A review on some drained reclamation works in Hong Kong, GEO report no. 63, prepared by JSM Kwong, Hong Kong.

Geotechnical Engineering Office 2008, Hong Kong geology guide book, The Government of the Hong Kong Special Administrative Region, Hong Kong.

Highways Department 2010, Hong Kong-Zhuhai-Macao Bridge, The Government of the Hong Kong Special Administrative Region, viewed 26 February 2015, http://www http://hzmb.hk/eng/index.html

Hong Kong Geological Survey 2002, Geology of Tung Chung and Northshore Lantau Island, report no. 6, prepared by RJ Sewell \& PA Kirk, Geotechnical Engineering Office, Hong Kong.

Hong Kong Observatory, Predicted Tides at Chek Lap Kok, The Government of the Hong Kong Special Administrative Region, viewed 20 March 2015, http://www.hko.gov.hk/tide/eCLKtide.htm.

Mikkelsen, PE 2002, 'Cement-bentonite grout backfill for borehole instruments', Geotechnical News, December, pp. 38-42.

Mikkelsen, PE \& Green, GE 2003, 'Piezometers in fully grouted boreholes', in F Myrvoll (ed.), Proceedings of the Sixth International Symposium on Field Measurements in Geomechanics, CRC Press, London, pp. 545-553.

Simeoni, L, De Polo, F, Caloni, G \& Pezzetti, G 2011, 'Field performance of fully grouted piezometers', Proceedings of the Eighth International Symposium on Field Measurements in Geomechanics, Technische Universität Braunschweig, Berlin, $15 \mathrm{p}$.

The Government of the Hong Kong special Administrative Region 2002, Port works design manual: part 3 - guide to design of reclamation, prepared by the Civil Engineering Office, Hong Kong.

Yungwirth, G, Preene, M, Dobr, M \& Forero Garcia, F 2013, 'Practical application and design considerations for fully grouted vibrating wire piezometers in mine water investigations', in C Wolkersdorfer, A Brown \& L Figueroa (eds), Proceedings of the International Mine Water Association Conference, International Mine Water Association Golden, Wendelstein, pp. 229-236. 